\title{
Relationship Between Trade Openness, Capital Formation and Economic Growth: A Panel Data Analysis for African Countries
}

\author{
Prof. Dr. Ahmet Ay (Selçuk University, Turkey) \\ Asst. Prof. Dr. Fahri Kurşunel (Selçuk University, Turkey) \\ Ph.D. Candidate Mahamane Moutari Abdou Baoua (Selçuk University, Turkey)
}

\begin{abstract}
The more a country is open to trade, the more it attracts investors and the faster its economy develops. However, some study showed that sometimes it can be the opposite of all this. In this context, the main purpose of this study is to investigate the relationship between trade openness, capital formation and economic growth in African countries. To do so, we collected data of GDP per capita, trade (\% of GDP), Gross national expenditure and capital formation variables. The method applied is panel cointegration and causality by using time series of 38 African countries for the period of 1990-2014. According to the results there is long run relationship between all the variables and the cross-sectional co-integration test result indicates that there is more cointegration in Comoros, Equatorial Guinea, Niger and Guinea-Bissau. With highest GDP per capita, Equatorial Guinea has more long-run relationship between trade openness, capital formation and economic growth. However, one of the poorest countries in the world (Niger), has also efficient long run relationship between the variables. The panel causality test results suggest that there is unidirectional causal relationship from trade openness to economic growth. There is also bidirectional causality link between capital formation and economic growth. In the same context, causal link exists from capital formation to trade openness. The study suggests that African countries must increase the investment promotions in order to increase the capital formation and trade openness then to boost economic growth.
\end{abstract}

\section{Introduction}

In this world of globalization, trade openness becomes a subject of several discussions. Trade and investments are the most important keys used to boost the economic growth of a country. According to most of economists, trade openness is considered as a determinant of investments inflows or outflows and economic development of a country. Thus, more a country is open to trade; more foreign investments and foreign capitals enter to this country. The Deardorffs' Glossary of International Economics defined "Trade Openness as a measure of the extent to which an economy is open to trade, and sometimes also to inflows and outflows of international investment. This measure is obtained with the ratio of exports, imports sum to the GDP of a country.

Indeed, for decades and in a context of increasing internationalization of trade in goods and services, the macroeconomic consequences of trade openness in developing countries have been the subject of widespread debate. The economic literature continues to be enriched and diversified by the experience of different countries, depending on whether they are emerging, developed or developing countries. Among the effects of economic growth, many support the preponderant role played by the process of trade openness in the improvement of property through an increase in productivity. Developments in theories of economic growth have highlighted the important role of trade openness as a factor that can promote long-term growth and productivity. Indeed, almost all empirical studies conclude that there is a causal link between trade openness and economic growth (Michaely, 1977, Frankel and Romer, 1999).

Despite the consensus on the beneficial effects of trade openness on developing countries, there is great difficulty in providing a theoretical and empirical justification for this presumed link between trade openness and its effects on growth economic. From a theoretical point of view, it is easy to prove the existence of a gain on growth from the static point of view. However, there is difficulty in bringing this reasoning from a dynamic point of view. In the late 1990s, openness policies were challenged because of their social impact in some developing countries. And to this end, several concerns have been expressed about the possibilities of opening trade to its beneficial effects on the economy. The majority of African countries are low-income countries and the fear of a polarization of the zone's activities in favor of a group of emerging countries of the zone is felt.

In this context, the main purpose of this study is to investigate the relationship between Trade openness, Capital Formation and economic growth for 38 African countries. In this optic, we will use the Johansen panel cointegration test and Granger panel causality test to investigate the long-run relationship and causality between trade openness, capital formation and economic growth.

In this framework, our work is organized as follow: the first section provides the theoretical framework. The second section explains the literature review, while the third section provide the data and methodology. Empirical results are giving in the fourth section and we conclude in the fifth section. 


\section{Theoretical Framework}

The traditional theories of international trade cannot explain trade between countries by neglecting the role of multinational films. These questions are answered within the framework of the new theory of international trade, based on the principles of imperfect competition and increasing returns to scale. However, the gains of the opening are perceived in a static way. However, until the late 1980s, growth theory could not answer such questions, since according to the traditional analysis derived from the Solow model (1956), growth was explained only by exogenous factors.

As the measure of economic growth is the change in gross domestic product (GDP), the crisis of the 1970s led to the emergence of qualitative criteria by posing the problem of the distribution of the components of growth. In order to promote population-based growth, the priorities were agriculture, health and education. In the second half of the 1980s, the concept of sustainable human development reappeared and is seen as the end and means of economic growth. Attempts to take into account the welfare of the population have led to the consideration of income, education, health and so on. Thus, we agree that growth is a process that is characterized by an increase in the long term, the real product per head in the direction of improvement of the welfare of the entire population. The presentation of growth models is a means of analyzing the determinants of economic growth. These models also make it possible to define the measures favoring the long-term development of economic activity. It is therefore necessary to identify the characteristics of the growth process for identification and classification purposes. Indeed, up to the classics, the questions of economic growth have evolved in parallel with those of international trade. The discussion of this problem starts from the development of international trade patterns (BADIO 2016, 6-8).

Reducing trade barriers adjusts domestic prices to world prices and forces firms to be more efficient. The choice of an inappropriate technology leads to a price disadvantage in the international market or in a highly competitive domestic market. In conclusion, strong protection entails technical efficiency and distortions that could hamper the growth of firms. In order for productivity gains to be linked, international trade must not to be hindered by artificial obstacles. This approach goes further than the view that the cost of protectionism lies in the fact that it attracts resources to the protected sectors rather than to those for which the country has real comparative advantages. In addition, sustained trade openness should in principle not only encourage investment in the internal market but also attract it to export sectors. However, a high tariff can attract capital formation to bypass it to serve the local market. Units implanted under these conditions are poor performers or lose their competitiveness, for export, over time. On the other hand, a weakly protected market receives export-oriented capital formation.

\section{Literature Review}

Since the main purpose of this study is investigate the relationship between Trade openness and economic growth for African countries, firstly we will look at some studies that did the same investigation for this variables. We will divide our literature review into three (3) parts: Studies applied to Africa or (individually) to african countries, Studies applied to developping countries and Studies applied to other countries.

Let's start with the studies applied to Africa or (individually) to african countries. In this context, Lemzoudi (2005) found a positive relationship between trade openness and GDP for two of the three coastal countries (Benin, Gahana and Nigeria) while examining whether the degree of openness affects the economic growth of coastal and landlocked countries in west Africa (Benin, Burkina Faso, Ghana, Mali, Niger and Nigeria) of these countries for the period 1980-2002. The results obtained are similar to those of Jin (2004) and show also a negative relationship for the three landlocked countries (like Niger, Burkina and Nali). These results suggest that countries with no direct access to a port are less outward oriented than coastal countries and consequently do not have a national economy strong enough to cope with foreign competition. Thompson (2011) also used a panel of forty two sub Saharan Africa (SSA) countries over the period 1980-2003 to examine the link between trade openness, infrastructure, foreign direct investment and economic growth. He found that FDI depends on trade openness and GDP per capita and that the interaction between trade openness and infrastructure leads to a slight increase in FDI inflows. Thompson also emphasizes that FDI has a positive and significant effect on growth; and he suggests that policy makers must further increase efforts towards trade openness and infrastructural development to enhance the level of FDI inflow for sustainable growth. However, Constant (2010) investigated the long-run impact of FDI and trade openness on economic growth in Ivory Cost by using the bounds testing co-integration approach and the VAR Granger causality/Block Exogeneity Wald tests. He found a long run relationship between the foreign direct investment, trade openness and growth; and according to the VAR Granger causality/Block Exogeneity Wald tests, there is unidirectional causal relationship running from FDI, trade openness to economic growth and from output, FDI to trade openness. Constant also recommends that, the Ivory Cost by the opportunities offered by world markets have to manage a good combination with a domestic investment and institution-building strategy to attract more inflows of FDI for economic growth dynamics.

Now let us view the studies applied to developping countries; among them there is the study of Basu, Chakraborty, \& Reagle (2003). They used a panel cointegration framework to examine the relation between FDI 
and growth; then the impact of liberalization on the dynamics of the FDI and GDP relationship for 23 developing countries. According to the results, there is a long-run cointegrating relationship between FDI and GDP and also a bidirectional causality between GDP and FDI for more open economies. For relatively closed economies, there is a long-run unidirectional causality from GDP to FDI, implying that growth and FDI are not mutually reinforcing under restrictive trade and investment regimes. However Hsiao \& Hsiao (2006) investigated the causality link between GDP, exports, and FDI among the eight rapidly developing East and Southeast Asian economies (China, Korea, Taiwan, Hong Kong, Singapore, Malaysia, Philippines, and Thailand) by using time-series and panel data from 1986 to 2004. According to the results each country has different causality relations and does not yield general rules. So the panel data causality results suggest that FDI has unidirectional effects on GDP directly and also indirectly through exports, and there also exists bidirectional causality between exports and GDP for the group. In other hand results found that the panel data causality analysis has superior results over the time-series causality analysis. In other hand, Liargovas \& Skandalis (2012) examined the importance of trade openness for attracting Foreign Direct Investment, by using a sample of 36 developing economies for the period 1990-2008. They found that in the long run, trade openness contributes positively to the inflow of FDI in developing economies. However, Nair-Reichert \& Weinhold (2001) used a mixed fixed and random (MFR) panel data estimation method to examine the possibility that the effect of FDI on growth could display quite heterogeneous behavior in a panel of 24 developing countries over 25 years. They found that the relationship between (both foreign and domestic) investment and economic growth in developing countries is highly heterogeneous and that estimation methods, which assume homogeneity across countries, can yield misleading results. Then they suggest that there is some evidence that the efficacy of FDI in raising future growth rates, although heterogeneous across countries, is higher in open economies. BADIO (2016) examined the effect of trade openness and foreign direct investment on economic growth by using the method of the instrumental variables and OLS, considering a sample of 114 developed and developing countries over a period from 1985 to 2011. According the results, when trade openness increases by one standard deviation, growth increases by 0.152 for the entire sample.

The review of studies applied to other countries is quite arguable. In this context, Çinko (2009) investigated the macroeconomic effects of foreign direct investment and introduced precautionary measures for Turkey. He stated that, foreign direct investment increases capital accumulation by contributing to the national income growth and affects positively the macroeconomic indicators. However, Ramzan \& Kiani (2012) applied an econometric technique of Error Correction Methods (ECM) in order to find the link between economic growth indicator, FDI, and trade openness by using the annual data set ranging from 1975 to 2011 . The results suggested that FDI and trade promote growth of real sector of economy of Pakistan. Differently, Bibi (2014) Investigated the role of trade openness, inflation, imports, exports, real exchange rate and foreign direct investment in enhancing economic growth in Pakistan by using analysis based on time series data for the period 1980 to 2011. According to the results, there is long run relationship among the variables and the FDI and trade increase the influence of economic growth. However, negative impact of trade openness could be surmounted by producing import substitutes and creating conditions for trade surplus. Mohen (2015) investigated the impact of trade openness, capital and oil price on the industrial outputs in Syria for the period of 1970-2010 by using time series analysis. According to the results, capital is positively significant related to industrial outputs, while trade openness and oil price are negatively significant related to industrial outputs in Syria. However, capital has the biggest impact on the industrial outputs. In other hand, there is unidirectional causality relationship running from oil price to industrial output and bidirectional causality relationships between trade openness, capital and industrial output in the long run. Besides, there are bidirectional causality relationship between capital and industrial output, and unidirectional causality relationships running from trade openness and oil price to industrial output in the short run. However, Adhikary (2015) investigated the relationship between FDI, trade openness, capital formation, human capital, and economic growth in Nepal using the vector-error correction model. He found there is a long-run equilibrium relationship between variables and that trade openness and FDI have a dynamic positive effect on the GDP per capita growth rate in Nepal. The Granger causality test indicates a unidirectional short-term causal flow runs between FDI, trade openness, and GDP per capita growth rate. However, the impulse-response analysis reveals that this relationship is not stable rather volatile over time. Adhikary suggests that Nepal should adopt more liberalized trade policy to attract foreign capitals and to ensure stable economic growth rate. Differently, Topalli (2016) examine the link between FDI, trade openness and economic growth in the BRICS countries and Turkey during the period 19822013 by using unit root test and causality test. The results found that there is unidirectional causality running from economic growth to FDI. Besides, there is bi-directional causality between economic growth and trade openness. However, mixed evidence is obtained according to individual country results.

We can emphasize that most of the studies found a positive relationship between FDI, trade and economic growth. 


\section{Data \& Methodology}

\subsection{Empirical Methodology}

The estimation that we will use in this study is based on the time series data, we will respects the rules for time series analysis. First, we will be sure that our variables are stationary or not. To do so we have to do the stationary test. The stationarity tests help us to check whether a series is stationary or not. There are two different types of tests: stationarity tests for which the null hypothesis H0 is that the series are stationary, such as the KPSS test. The second test type is unit root tests for which the null hypothesis is that the series are not stationary such as PhillipsPerron (PP) test or the Dickey-the unit root test developed by Dickey \& Fuller (1979) and that everyone konws as Dickey-Fuller Test (or DF Test). The standard DF test is a stationarity test that only concerns first order autoregressive processes or AR (1) process. The Dickey-Fuller test was then extended by the Augmented Dickey and Fuller test (or ADF test) to detect the presence of a unit root for AR (p) type processes. In this study we will use ADF test to detect the unit root for AR(p). The ADF test consists in estimating the preceding models by introducing delayed variables. You can read many books and articles explaining the method of ADF unit root test (Sevüktekin ve Nargeleçekenler 2010, 305-331).

After the unit root test, we will use the co-integration test to detect the long-term relationship between our variables. Co-integration is a statistical property of time series introduced in economic analysis, to detect the longterm relationship between two or more time series. Formally, if the available time series are integrated in first order, and in addition a linear combination of these series is integrated of order zero (stationary), we will then say that the varieties are co-integrated of order I(1). The econometric literature distinguishes different techniques for testing co-integration, among which we can cite: the Granger-Engel algorithm (1987); the approaches of Johansen (1988, 1991); The Stock-Watson test (1988); The Phillips-Ouliaris test (1990). In this study we will use Johansen approach of co-integration. The co-integration test of JOHANSEN helps us on the number of co-integration relation and its functional form by following the criterion of trace and minimum eigenvalue and also the information criteria of AKAIKE and SCHWARZ. The test hypothesis is formulated as follows:

$\mathrm{H} 0$ : There is a co-integration relation;

$\mathrm{H} 1$ : There is no co-integration relationship.

If the value of the trace and Max-eigenvalue is greater than its tabulated critical value, the hypothesis $\mathrm{H} 0$ is rejected, indicating that there is co-integration between the variables. On the other hand, a value of the trace and Max-eigenvalue lower than its critical value implies that there is no co-integration relation between the variables (Tar1 2011, 416-429).

What is the cause of the relationship between the variables used in a given model? We will use causality test to determine whether one time series is useful in forecasting another. Causality was introduced in the econometric analysis by Wiener (1956) and Granger (1969). The basic idea of causality in Granger's sense is that a temporal series $\mathrm{x} 1, \mathrm{t}$ would cause another series $\mathrm{x} 2, \mathrm{t}$ when the knowledge of the past of $\mathrm{x} 1, \mathrm{t}$ leads to a prediction of $\mathrm{x} 2, \mathrm{t}$ distinct from that based solely on the past of $\mathrm{x} 2$,t. In other words, in a time series $\mathrm{x} 1$, t causes another series $\mathrm{x} 2, \mathrm{t}$, if conditioned to the past values of $\mathrm{x} 1, \mathrm{t}$ the mean squared error of $\mathrm{x} 2, \mathrm{~T}+1$ is less than that where the information about past values of $x 1, t$ was omitted. There is several econometric studies such as (Gujarati 2009, 652656) which explained how the Granger causality test works (Tarı 2011, 436-437).

\subsection{Data}

The data used in this model was downloaded from the World Development Indcators database of World Bank. We collected data of Trade (\% of GDP), Foreign direct investment - net inflows (\% of GDP), Gross capital formation ( $\%$ of GDP), Gross national expenditure (\% of GDP) and GDP per capita.In the model, we specified the endogenous variable as gross domestic product (GDP) as a function of trade openness (TP), Foreign direct investment (FDI), Capital Formation (GCF) and National Expenditure (GNE) all representing the exogenous variables. All data are from World Economic Outlook database of World Bank in constant (base year:2010) US dollar. Table-1 shows the descriptive statistics of the time series variables.

\subsection{Model Specification}

We will formulate our model from a Cobb Douglas production of physical capital (K), human capital (L), and technical progress (A).

$Y=A K^{a} L^{b}$

Let give a linear form to the equation:

$\log (y)=\log (A)+\operatorname{alog}(K)+b \log (L)$

Let us put this equation to our model. Then we will have the following specification:

$\mathrm{GDP}=a_{0}+a_{1} T P+a_{3} G C F+a_{4} G N E+\varepsilon_{i t}$

Where

GDP $=$ real GDP per capita 
$\boldsymbol{T P}=$ Trade openness

$\boldsymbol{G C F}=$ Gross Capital Formation

$\boldsymbol{G N E}=$ National Expenditure

Where $\boldsymbol{\alpha}_{\boldsymbol{\theta}}$ is the constant term and $\boldsymbol{\alpha}_{1}$ to $\boldsymbol{\alpha}_{4}$ are coefficients of the explanatory variables. $\boldsymbol{\varepsilon}$ is the stochastic error term. In the model, real GDP per capita is used as dependent variable as a proxy for real growth.

\section{Empirical Results}

\subsection{Stationarity}

In the stationary test, we used the global probability results to investigate the presence of unit root within the variables. We performed the stationary investigation with $5 \%$ efficiency. In summary, we found that there is unit root within the variables in level. The ADF unit root test in first difference shows that all variables are stationary in $5 \%$ efficiency level.

\begin{tabular}{|l|c|c|c|c|c|c|c|c|}
\hline & \multicolumn{4}{|c|}{ Level } & \multicolumn{4}{c|}{ First Difference } \\
\cline { 2 - 9 } & Intercept & $\begin{array}{c}\text { Intercept } \\
\text { \& Trend }\end{array}$ & None & Efficiency 5\% & Intercept & $\begin{array}{c}\text { Intercept } \\
\text { \& Trend }\end{array}$ & None & Efficiency 5\% \\
\hline TP & 0,02 & 0,00 & 1,00 & Non-Stationnary & 0,00 & 0,00 & 0,00 & Stationnary \\
\hline GDP & 0,99 & 0,39 & 1,00 & Non-Stationnary & 0,00 & 0,00 & 0,00 & Stationnary \\
\hline GCF & 0,01 & 0,00 & 0,99 & Non-Stationnary & 0,00 & 0,00 & 0,00 & Stationnary \\
\hline GNE & 0,00 & 0,00 & 1,00 & Non-Stationnary & 0,00 & 0,00 & 0,00 & Stationnary \\
\hline
\end{tabular}

Table 1: ADF Unit Root Test Results

\subsection{Cointegration}

After the stationary test let's perform the co-integration analysis that consist of examining whether the variables are in long-term relationship or not. The results of the cointegration rank test by trace and max-eigenvalue is given in Table-2 and Table-3.

\begin{tabular}{ccccc}
\hline \hline $\begin{array}{c}\text { Hypothesized } \\
\text { No. of CE(s) }\end{array}$ & $\begin{array}{c}\text { Fisher Stat.* } \\
\text { (from trace test) }\end{array}$ & Prob. & $\begin{array}{c}\text { Fisher Stat. } \\
\text { (from max-eigen test) }\end{array}$ & Prob. \\
\hline \hline None & 747.0 & 0.0000 & 542.3 & 0.0000 \\
At most 1 & 312.8 & 0.0000 & 223.6 & 0.0000 \\
At most 2 & 163.9 & 0.0000 & 130.8 & 0.0001 \\
At most 3 & 146.7 & 0.0000 & 146.7 & 0.0000 \\
\hline \hline
\end{tabular}

* Probabilities are computed using asymptotic Chi-square distribution.

Table 2: Unrestricted Cointegration Rank Test (Trace and Maximum Eigenvalue)

According to Table-2 the global co-integration result shows that there is presence of four co-integrated vectors and that there is long run relationship between the variables. In order to verify the long run relationship between the variables for the cross-section entities, the cross-section cointegration test result is given in Table-3.

According to Table-3, there is more cointegration in Comoros, Equatorial Guinea, Niger and Guinea-Bissau. 


\begin{tabular}{|c|c|c|c|c|c|c|c|c|}
\hline Cross Section & $\begin{array}{l}\text { Trace } \\
\text { Test }\end{array}$ & $\begin{array}{c}\text { Max- } \\
\text { Eign Test }\end{array}$ & $\begin{array}{l}\text { Trace } \\
\text { Test }\end{array}$ & $\begin{array}{c}\text { Max- } \\
\text { Eign Test }\end{array}$ & $\begin{array}{l}\text { Trace } \\
\text { Test }\end{array}$ & $\begin{array}{c}\text { Max- } \\
\text { Eign Test }\end{array}$ & $\begin{array}{l}\text { Trace } \\
\text { Test }\end{array}$ & $\begin{array}{c}\text { Max- } \\
\text { Eign Test }\end{array}$ \\
\hline Benin & 0 & 0.0013 & 0.0009 & 0.0074 & 0.0361 & 0.06 & 0.1021 & 0.1021 \\
\hline Botswana & 0.0344 & 0.0879 & 0.2028 & 0.2965 & 0.3607 & 0.562 & 0.1037 & 0.1037 \\
\hline Burkina Faso & 0.0033 & 0.0007 & 0.5249 & 0.3968 & 0.8154 & 0.8035 & 0.5072 & 0.5072 \\
\hline Burundi & 0.0004 & 0.0239 & 0.008 & 0.03 & 0.0971 & 0.1249 & 0.1703 & 0.1703 \\
\hline Cameroon & 0 & 0 & 0.182 & 0.4059 & 0.2155 & 0.4384 & 0.0615 & 0.0615 \\
\hline Central African Republic & 0.0114 & 0.0448 & 0.1224 & 0.1536 & 0.3837 & 0.5602 & 0.1223 & 0.1223 \\
\hline Chad & 0 & 0 & 0.1361 & 0.0948 & 0.6142 & 0.5282 & 0.9114 & 0.9114 \\
\hline Comoros & 0 & 0.0003 & 0.0005 & 0.0168 & 0.0096 & 0.0448 & 0.0191 & 0.0191 \\
\hline Congo, Rep. & 0 & 0.0009 & 0.0005 & 0.0045 & 0.0306 & 0.041 & 0.1488 & 0.1488 \\
\hline Cote d'Ivoire & 0.0001 & 0.0004 & 0.0358 & 0.2028 & 0.0669 & 0.1015 & 0.1221 & 0.1221 \\
\hline Egypt, Arab Rep. & 0 & 0 & 0.017 & 0.0185 & 0.3141 & 0.2735 & 0.5129 & 0.5129 \\
\hline Equatorial Guinea & 0 & 0.0039 & 0 & 0.0041 & 0.0018 & 0.0148 & 0.0091 & 0.0091 \\
\hline Gabon & 0.0037 & 0.001 & 0.4884 & 0.4855 & 0.646 & 0.7193 & 0.2652 & 0.2652 \\
\hline Ghana & 0.0004 & 0.0023 & 0.0636 & 0.0404 & 0.5681 & 0.6148 & 0.2955 & 0.2955 \\
\hline Guinea & 0 & 0 & 0.0011 & 0.0009 & 0.2835 & 0.2925 & 0.3077 & 0.3077 \\
\hline Guinea-Bissau & 0 & 0 & 0 & 0.0015 & 0.0037 & 0.0552 & 0.0034 & 0.0034 \\
\hline Kenya & 0 & 0.0001 & 0.0059 & 0.0256 & 0.083 & 0.0743 & 0.3589 & 0.3589 \\
\hline Madagascar & 0.0021 & 0.0109 & 0.0767 & 0.1112 & 0.3125 & 0.3836 & 0.1987 & 0.1987 \\
\hline Malawi & 0 & 0 & 0.2403 & 0.6162 & 0.1664 & 0.4188 & 0.0407 & 0.0407 \\
\hline Mali & 0.147 & 0.1352 & 0.5334 & 0.5703 & 0.616 & 0.5972 & 0.4595 & 0.4595 \\
\hline Mauritania & 0.0056 & 0.0107 & 0.183 & 0.5295 & 0.1457 & 0.1684 & 0.2183 & 0.2183 \\
\hline Mauritius & 0.0143 & 0.2464 & 0.0295 & 0.1261 & 0.0934 & 0.3376 & 0.0223 & 0.0223 \\
\hline Morocco & 0.0003 & 0.0119 & 0.0104 & 0.0783 & 0.0477 & 0.1444 & 0.0353 & 0.0353 \\
\hline Mozambique & 0.0001 & 0.0009 & 0.022 & 0.0401 & 0.2139 & 0.3144 & 0.1303 & 0.1303 \\
\hline Namibia & 0 & 0.0005 & 0.0168 & 0.0261 & 0.2355 & 0.3274 & 0.1476 & 0.1476 \\
\hline Niger & 0 & 0.008 & 0.0001 & 0.0131 & 0.0024 & 0.0476 & 0.0024 & 0.0024 \\
\hline Nigeria & 0 & 0 & 0.0029 & 0.0181 & 0.0548 & 0.0518 & 0.3026 & 0.3026 \\
\hline Rwanda & 0 & 0 & 0.0285 & 0.3064 & 0.0283 & 0.0792 & 0.0419 & 0.0419 \\
\hline Senegal & 0.0516 & 0.3961 & 0.0706 & 0.4192 & 0.0573 & 0.0706 & 0.1797 & 0.1797 \\
\hline Sierra Leone & 0.0089 & 0.0981 & 0.048 & 0.0224 & 0.6474 & 0.8861 & 0.1022 & 0.1022 \\
\hline South Africa & 0.0006 & 0.0249 & 0.0106 & 0.0357 & 0.1114 & 0.088 & 0.514 & 0.514 \\
\hline Sudan & 0.0002 & 0.0005 & 0.0793 & 0.0836 & 0.4116 & 0.3327 & 0.8273 & 0.8273 \\
\hline Swaziland & 0.0021 & 0.0109 & 0.0772 & 0.1807 & 0.1939 & 0.1765 & 0.3974 & 0.3974 \\
\hline Tanzania & 0.0001 & 0.0009 & 0.0244 & 0.0291 & 0.309 & 0.3586 & 0.2295 & 0.2295 \\
\hline Togo & 0.0257 & 0.0602 & 0.2064 & 0.2441 & 0.4462 & 0.437 & 0.3935 & 0.3935 \\
\hline Tunisia & 0 & 0 & 0.0074 & 0.0037 & 0.4839 & 0.3966 & 0.964 & 0.964 \\
\hline Uganda & 0.0003 & 0.0452 & 0.0027 & 0.0483 & 0.0177 & 0.0114 & 0.6401 & 0.6401 \\
\hline Zimbabwe & 0 & 0.0009 & 0.006 & 0.0237 & 0.0901 & 0.0631 & 0.7146 & 0.7146 \\
\hline
\end{tabular}

Table 2: Cross-Section Cointegration Results

With highest GDP per capita, Equatorial Guinea has more long-run relationship between trade openness, capital formation and economic growth. However, one of the poorest country in the world (Niger) has also efficient long run relationship between the variables.

\subsection{Panel Causality Test}

After the long run relationship investigation, let us examine the causality between the variables. The causality test results are given in Table-4.

Date: 02/07/17 Time: 18:25

Sample: 19902014

Lags: 4

\begin{tabular}{lccc}
\hline \hline Null Hypothesis: & W-Stat. & Zbar-Stat. & Prob. \\
\hline \hline TP does not homogeneously cause GDP & 7.60734 & 3.85427 & 0.0001 \\
GDP does not homogeneously cause TP & 7.84117 & 4.17530 & 3. E-05 \\
\hline \hline GCF does not homogeneously cause GDP & 7.08242 & 3.13360 & 0.0017 \\
GDP does not homogeneously cause GCF & 7.25191 & 3.36629 & 0.0008 \\
\hline \hline GNE does not homogeneously cause GDP & 8.28010 & 4.77792 & $2 . E-06$ \\
GDP does not homogeneously cause GNE & 7.56112 & 3.79081 & 0.0002 \\
\hline \hline GCF does not homogeneously cause TP & 7.18409 & 3.27317 & 0.0011 \\
TP does not homogeneously cause GCF & 5.39587 & 0.81808 & 0.4133 \\
\hline GNE does not homogeneously cause TP & 7.05957 & 3.10222 & 0.0019 \\
TP does not homogeneously cause GNE & 7.09637 & 3.15274 & 0.0016 \\
\hline \hline GNE does not homogeneously cause GCF & 4.31677 & -0.66343 & 0.5071 \\
GCF does not homogeneously cause GNE & 5.56230 & 1.04657 & 0.2953 \\
\hline \hline
\end{tabular}

Table 3: Pairwise Dumitrescu Hurlin Panel Causality Tests result 
According to Table-4, there is unidirectional causal relationship from trade openness to economic growth. There is bidirectional causality link between capital formation and economic growth. In the same context, causal link exists from capital formation to trade openness. Bidirectional causality link exists between national expenditure and trade openness and unidirectional causal link from economic growth to national expenditure. We can see the rejection of null hypothesis in the causality between national expenditure and capital formation, indicating that there is any causal link between the two variables.

\section{Conclusion}

Since the main purpose of our study is to investigate the relationship between Trade openness, Capital Formation and economic growth for 38 African countries, we used the Johansen panel cointegration test and Granger panel causality test to investigate the long-run relationship and causality between trade openness, capital formation and economic growth. Before performing cointegration and causality test we investigate the stationarity of variable by using the $\mathrm{ADF}$ unit root test. During the stationary test, we performed the stationary investigation with $5 \%$ efficiency. In summary, we found that there is unit root within the variables in level. The ADF unit root test in first difference shows that all variables are stationary in 5\% efficiency level. After the unit root test, we performed the cointegration test. According to the global co-integration result, there is long run relationship between all the variables. The cross sectional cointegration test result indicates that there is more cointegration in Comoros, Equatorial Guinea, Niger and Guinea-Bissau. With highest GDP per capita, Equatorial Guinea has more long-run relationship between trade openness, capital formation and economic growth. However, one of the poorest countries in the world (Niger), has also efficient long run relationship between the variables. The panel causality test results suggest that there is unidirectional causal relationship from trade openness to economic growth. There is also bidirectional causality link between capital formation and economic growth. In the same context, causal link exists from capital formation to trade openness. Bidirectional causality link exists between national expenditure and trade openness and unidirectional causal link from economic growth to national expenditure. We can see the rejection of null hypothesis in the causality between national expenditure and capital formation, indicating that there is any causal link between the two variables. The study suggests that African countries must increase the investment promotions in order to increase the capital formation and trade openness then to boost economic growth.

\section{References}

- Adhikary, Bishnu Kumar. 2015. "Dynamic Effects of FDI, Trade Openness, Capital Formation and Human Capital on the Economic Growth Rate in the Least Developed Economies: Evidence from Nepal." International Journal of Trade, Economics and Finance 6 (1): 1-7.

- Agrawal, Pradeep. 2005. "Foreign Direct Investment in South Asia: Impact on Economic Growth and Local Investment." In Multinationals and Foreign Investment in Economic Development, by Edward M. Graham, 94-118. London: Palgrave Macmillan UK.

- Asiedu, Elizabeth. 2002. "On the Determinants of Foreign Direct Investment to Developing Countries: Is Africa Different?" World Development 30 (1): 107-119.

- BADIO, Mélissa Sybille. 2016. Impact Des Investissements Directs Étrangers Et De L'ouverture Commerciale Sur La Croissance Économique. Master Thesis, Montréal: Université du Québec.

- Basu, Parantap, Chandana Chakraborty, and Derrick Reagle. 2003. "Liberalization, FDI, and Growth in Developing Countries: A Panel Cointegration Approach." Economic Inquiry 41 (3): 510-516.

- Bibi, Sadia. 2014. "Impact of Trade Openness, FDI, Exchange Rate and Inflation on Economic Growth: A Case Study of Pakistan." International Journal of Accounting and Financial Reporting 4 (2): 236-257.

- Constant, N'guessan Bi Zambe Serge. 2010. "The Relationship between Foreign Direct Investment, Trade Openness and Growth in Cote d'Ivoire." International Journal of Business and Management 5 (7): 99-107.

- Gujarati, Damodar N. 2009. Basic Econometrics. 5. Singapore: McGraw-Hill.

- Hsiao, Frank S.T., and Mei-Chu W. Hsiao. 2006. "FDI, Exports, and GDP in East and Southeast Asia - Panel Data versus Time-Series Causality Analyses." Journal of Asian Economics 6 (17): 1082-1106.

- Lemzoudi, Nadia. 2005. L'impact du degré d'ouverture sur la croissance économique: Cas de six pays d'Afrique de l'Ouest. Master Thesis, Economics, Montréal: Université de Montréal.

- Liargovas, Panagiotis G., and Konstantinos S. Skandalis. 2012. "Foreign Direct Investment and Trade Openness: The Case of Developing Economies." Social Indicators Research 106 (2): 323-331.

- Mohsen, Adel Shakeeb. 2015. "Linkages between Trade Openness, Capital, Oil Price and Industrial Outputs in Syria." Economic Insights - Trends and Challenges IV (3): 11-19. 
- Nair-Reichert, Usha, and Diana Weinhold. 2001. "Causality Tests for Cross-Country Panels: a New Look at FDI and Economic Growth in Developing Countries." Oxford Bulletin of Economics and Statistics 63 (2): 153-171.

- $\quad$ Ramzan, Danish, and Adiqa Kausar Kiani. 2012. "Analyzing the Relationship Between FDI, Trade Openness and Real Output Growth: An ECM Application for Pakistan." International Journal of Basic and Applied Science 1 (2): 440-447.

- $\quad$ Sakyi, Daniel, Richmond Commodore, and Eric Evans Osei Opoku. 2015. "Foreign Direct Investment, Trade Openness and Economic Growth in Ghana: An Empirical Investigation." Journal of African Business $16(1-2): 1-15$.

- Sevüktekin, Mustafa, and Mehmet Nargeleçekenler. 2010. Ekonometrik Zaman Serileri Analizi. Ankara: Nobel Yayın Dağıtım.

- Solow, R. M. 1965. "A contribution to the theory of economie growth." Quarterly Journal of Economies 1 (70): 65-94.

- Tar1, Recep. 2011. Ekonometri. 7. Kocaeli: Umuttepe Yayınları.

- Thompson, Abimbola Babatunde. 2011. "Trade Openness, Infrastructure, FDI and Growth in Sub-Saharan African Countries." Journal of Management Policy and Practice 7 (12): 27-36.

- Topalli, Nurgün. 2016. "Doğrudan Sermaye Yatirimlari, Ticari Dişa Açiklik ve Ekonomik Büyüme Arasindaki İlişki: Türkiye ve Brics Ülkeleri Örneği." Doğuş Üniversitesi Dergisi 17 (1): 83-95.

- World Bank. 2017. World Development Indicators. 0131. http://databank.worldbank.org/data/reports.aspx?source=world-development-indicators.

- Zekarias, Seiko Minota. 2016. "The Impact of Foreign Direct Investment (FDI) on Economic Growth in Eastern Africa: Evidence from Panel Data Analysis." Applied Economics and Finance 3 (1): 145-160 